\title{
Research article: Constraints as perceived by the respondents in adoption of recommended kitchen gardening techniques in district Amritsar, Punjab
}

\begin{abstract}
- PARVINDER SINGH, JAGMOHAN SINGH, B.S. DHILLON AND SUKHJINDERJIT SINGH
\end{abstract}

Article Chronicle: Received :

26.05.2017;

Revised :

07.06.2017;

Accepted :

21.06.2017

KeY Words :

Kitchen garden, Constraints,

Adoption

Author for correspondence :

\section{PARVINDER SINGH}

Krishi Vigyan Kendra, AMRITSAR (PUNJAB)

INDIA

Email:tungps1971-asr@

pau.edu

See end of the article for

authors' affiliations
SUMMARY : Vegetables help to combat malnutrition and diversify diets. Kitchen gardening may prove to be a boon for rural people to meet their daily requirements of vegetables and fruits. Most of the farm families having kitchen garden are interested to improve the practice of growing vegetables for their own use but they are facing various constraints. The present study was conducted with the objective to study the perceived constraints in adoption of kitchen gardening by the rural masses. Four villages were selected from different blocks of district Amritsar. Twenty five (25) farm families who were already practicing kitchen gardening were randomly selected from each village, consisting the total sample of 100 respondents (one from each family). The data were collected from each respondent through personal interview method with the help of structured schedule. The constraints as perceived by respondents scored on the basis of magnitude of the problem. The study highlighted that input constraint was most serious constraint followed by general constraints, technical constraints, sociocultural constraints and post-harvest constraints. Non - availability of quality planting material and seeds of HYVs of vegetables, lack of knowledge about improved varieties, seed rate and, sowing time, seed treatment, major pests and diseases, continuous use of traditional practices for growing vegetables and lack of interest among rural youth towards farming were considered the major constraints in successful adoption of kitchen gardening.

How to cite this article : Singh, Parvinder, Singh, Jagmohan, Dhillon, B.S. and Singh, Sukhjinderjit (2017). Constraints as perceived by the respondents in adoption of recommended kitchen gardening techniques in district Amritsar, Punjab. Agric. Update, 12(3): 347-350; DOI : 10.15740/HAS/AU/12.3/347-350. 